\title{
Preliminary results on exogenous ghrelin administration via stomach tube influence on the crypt cell proliferation in the small intestine mucosa of neonatal piglets*
}

\author{
M. Słupecka ${ }^{1}$ and J. Woliński ${ }^{2}$ \\ The Kielanowski Institute of Animal Physiology and Nutrition, \\ Department of Gastrointestinal Physiology, Polish Academy of Sciences \\ 05-110 Jabtonna, Poland
}

(Received 4 May 2007; revised version 1 June 2007; accepted 6 September 2007)

\begin{abstract}
The aim of this study was to investigate the exogenous ghrelin effect on proliferation in the small intestinal mucosa, body and organs weight of neonatal piglets. Four groups $(n=6)$ of pig neonates were examined: sow reared (C7SR), fed with milk formula (C7), fed with milk formula + ghrelin administrated via stomach tube in the dose of: $7.5 \mu \mathrm{g} / \mathrm{kg}$ body weight (BW) (G7.5) and $15 \mu \mathrm{g} / \mathrm{kg}$ BW (G15). Milk formula feeding (C7) strongly decreased mitotic rate in all parts of jejunum as compared to C7SR. Ghrelin treatment (G7.5) had a pro mitotic effect on the middle part of the small intestine $(\mathrm{P}<0.0001)$ as compared to $\mathrm{C} 7$. G15 treatment strongly increased the mitotic activity as compared to $\mathrm{C} 7(\mathrm{P}<0.0001)$ and C7SR $(\mathrm{P}<0.0001)$. Unlike other forms of treatment in $\mathrm{G} 15$ mitotic activity was constant along all parts of small intestine. Moreover, ghrelin treatment decreased BW and increased stomach weight. In conclusion, exogenous ghrelin administrated in the dose of 15 $\mu \mathrm{g} / \mathrm{kg} \mathrm{BW}$ for 6 days resulted in the increase of the crypt cell proliferation in the small intestine mucosa of neonatal piglets.
\end{abstract}

KEY WORDS: ghrelin, proliferation, small intestine, piglets

\footnotetext{
${ }^{*}$ Supported by the State Committee for Scientific Research, Grant No. PBZ-KBN-093/P06/2003

${ }^{1}$ Corresponding author: e-mail: m.slupecka@ifzz.pan.pl

${ }^{2} \mathrm{Dr}$ J. Woliński is a recipient of a Foundation for Polish Science (FNP) scholarship
} 


\section{INTRODUCTION}

Ghrelin is 28-amino acid peptide discovered as the endogenous ligand of the growth hormone (GH) secretagogue receptor (Kojima et al., 1999). Ghrelin was shown to strongly simulate GH release in vitro and in vivo in humans and rats (Baudet et al., 2003). Although ghrelin is predominantly produced in the stomach epithelium its presence was also detected in several other tissues e.g., in the pituitary, hypothalamus, pancreas, intestine and placenta (Gualillo et al., 2001; Dembinski et al., 2003). Ghrelin exhibits broad range of biological actions such as stimulation of food intake, regulation of energy balance, control of glucose metabolism, insulin secretion (Granata et al., 2007) and modulation of cell proliferation and survival in several cell lines (Pettersson et al., 2002; Karbonits et al., 2004; Maccarinelli et al., 2005; Granata et al., 2007). In the stomach, ghrelin stimulates gastric acid secretion and gastric motility in the anaesthetized rats (Masuda et al., 2000) and exhibits gastroprotective effect (Sibilia et al., 2003). Moreover, ghrelin and its receptor expression were found in the developing gastrointestinal foetal and neonatal tissues (Rindi et al., 2002). Those data, together with substantial amounts of ghrelin present in colostrum and milk (Woliński et al., 2006) suggest the ghrelin role in postnatal development.

The aim of this study was to estimate the influence of the exogenous ghrelin on the crypt cell proliferation in the small intestine mucosa of neonatal piglets.

\section{MATERIAL AND METHODS}

The experiments and treatments were conduced in compliance with the European Union regulations concerning protection of the experimental animals. The study protocol approved by the Local Ethics Committee.

A total of 24 male neonatal piglets (Polish Landrace x Pietrain) from 12 different litters were purchased from a commercial pig farm. For the first $24 \mathrm{~h}$ all piglets were kept with their sows. After this period they were randomly divided into 4 groups $(n=6)$ depending on the conditions of the further treatment. Six of them were left with their sows for the next 6 days (C7SR) and the rest were delivered to the laboratory (4 piglets for each trial) and installed in cages equipped in, so called, artificial sows - microprocessor operated system which provides equal amounts of milk replacement (Research Center Foulum-model, Pig's oline, Boss' Produkter a/s, Denmark). Milk replacer formula for piglets (protein: 19.8\%; fat: 19.7\%; Lakti R, Polfarma, Poland) was supplied to each piglet every $75 \mathrm{~min}$ (20 times per $24 \mathrm{~h}$ ) by means of an artificial sow. Body weight was recorded every morning. The control group (C7) received milk formula and $5 \mathrm{ml} 0.9 \% \mathrm{NaCl}$ via stomach tube every $8 \mathrm{~h}$. The ghrelin groups received milk formula and additionary 
ghrelin (rat ghrelin, Yanaiara Institute, Japan) via: stomach tube in a dose of 7.5 $\mu \mathrm{g} / \mathrm{kg} \mathrm{BW}(\mathrm{G} 7.5)$ or $15 \mu \mathrm{g} / \mathrm{kg} \mathrm{BW}$ (G15) every $8 \mathrm{~h}$.

After six days of vehicle or hormone treatment the animals were sacrificed by a pentobarbiturate (Vetbutal, Biowet, Poland) overdose. GI organs (stomach, liver and pancreas) weight was recorded (Table 1) and samples of duodenum, jejunum and ileum were collected and immediately fixed in 10\% neutral formalin solution.

Table 1. Body weight (kg) and organ morphometry (g/kg BW) in sow reared piglets (C7SR), fed with milk formula (C7) and supplemented with ghrelin (ZG7.5 - $7.5 \mu \mathrm{g} / \mathrm{kg} \mathrm{BW;} \mathrm{ZG15} \mathrm{-} 15 \mu \mathrm{g} / \mathrm{kg}$ BW)

\begin{tabular}{lcccc}
\hline \multirow{2}{*}{ Group } & Body weight & \multicolumn{3}{c}{$\mathrm{g} / \mathrm{kg}$ body weight } \\
\cline { 3 - 5 } & $\mathrm{kg}$ & stomach & liver & pancreas \\
\hline C7SR & $2.71 \pm 0.43^{\mathrm{a}}$ & $5.00 \pm 0.54^{\mathrm{a}}$ & $28.02 \pm 2.16^{\mathrm{a}}$ & $1.55 \pm 0.13$ \\
C7 & $2.40 \pm 0.46^{\mathrm{a}}$ & $5.97 \pm 1.09$ & $39.26 \pm 6.14^{\mathrm{b}}$ & $1.87 \pm 0.33$ \\
G 7.5 & $1.98 \pm 0.17$ & $7.53 \pm 0.71^{\mathrm{b}^{*}}$ & $28.25 \pm 3.92^{* *}$ & $1.77 \pm 0.23$ \\
G 15 & $1.84 \pm 0.18^{\mathrm{b}^{* *}}$ & $6.97 \pm 0.93^{\mathrm{b}^{*}}$ & $32.26 \pm 6.24^{* *}$ & $1.79 \pm 0.39$ \\
P & 0.0009 & 0.0024 & 0.0008 & 0.1036 \\
\hline
\end{tabular}

values are given as means \pm SD $(n=6)$

a,b - in the columns indicate statistical difference between groups. Kruskal-Wallis test followed by the Dunn's Multiple Comparison test. Asteriks indicate statistical difference between C7 vs G7.5; C7 vs G15 groups (Unpaired t-test or Mann-Whitney test)

To estimate the mitosis rate the slides were stained for Ki67 (Abcam GB) according to standard protocol (En Vision+ System-HRP(DAB), DakoCytomation DE). Ki67 positive cells were observed under the light microscopy (Zeiss, Germany) and 20 whole crossections per slide of (well-oriented) intestinal crypts were examined. The mitotic rate was estimated as a number of Ki67 positive cells per crypt (mean of 20 crypts)

The data are expressed as their means and standard deviation (SD). KruskalWallis test followed by the Dunn's Multiple Comparison test, unpaired t-test or Mann-Whitney tests were used to indicate the statistical differences between the groups (Graph Pad Software version 4.0, San Diego, CA, USA). In all statistical analysis $\mathrm{P}<0.05$ was taken as the level of significance.

\section{RESULTS}

Six days of ghrelin treatment resulted in a slight (G7.5) and significant (G15) reduction of body weight as compared with the control groups (C7SR, C7; Table 1). The weight of the stomach showed a significant increase in the piglets treated with both doses of ghrelin (C7SR vs C7 vs G7.5 vs G15, P=0.0024; C7 vs G7.5, $\mathrm{P}=0.03 ; \mathrm{C} 7$ vs $\mathrm{G} 15, \mathrm{P}=0.02$ ). Exogenous ghrelin treatments significantly decrease 
the liver weights relatively to the body weight compared with C7 groups (Table 1). Was no observed ghrelin effect on the pancreas weight.

The results of mitotic index analyses are shown in Table 2. In sow-reared piglets (C7SR) mitotic index was significantly reduced in the middle and distal part of jejunum and ileum, whereas in the milk formula-fed (C7) and ghrelinsupplemented piglets (G7.5) also in the prox-jejunum. However, in the ghrelinsupplemented group (G15) mitotic index was significantly decreased in the proximal part of jejunum and very stable in all other parts of small intestine (Table 2).

Table 2. Mitotic index in duodenum, proximal, middle, distal jejunum and ileum in sow reared piglets (C7SR), fed with milk formula (C7) and supplemented with ghrelin (ZG7.5 - $7.5 \mu \mathrm{g} / \mathrm{kg} \mathrm{BW}$; ZG15 - $15 \mu \mathrm{g} / \mathrm{kg} \mathrm{BW)}$

\begin{tabular}{|c|c|c|c|c|c|c|}
\hline \multirow{2}{*}{ Group } & \multirow{2}{*}{ Duodenun } & \multicolumn{3}{|c|}{ Jejunum } & \multirow{2}{*}{ Ileum } & \multirow{2}{*}{$\mathrm{P}$} \\
\hline & & proximate & mid & distal & & \\
\hline C7SR & $2.26 \pm 1.01^{\mathrm{aA}}$ & $1.84 \pm 0.79^{\mathrm{aAC}}$ & $1.78 \pm 0.84^{\mathrm{acBC}}$ & $1.62 \pm 0.86^{\mathrm{acBC}}$ & $1.69 \pm 0.92^{\mathrm{acBC}}$ & $<0.0001$ \\
\hline $\mathrm{C} 7$ & $2.32 \pm 0.92^{\mathrm{aA}}$ & $1.26 \pm 0.75^{\mathrm{bB}}$ & $0.99 \pm 0.66^{\mathrm{bBC}}$ & $1.24 \pm 0.76^{\mathrm{bB}}$ & $1.39 \pm 0.95^{\mathrm{aBD}}$ & $<0.0001$ \\
\hline G7.5 & $1.65 \pm 0.73^{\mathrm{bcA}}$ & $1.11 \pm 0.61^{\mathrm{bB}}$ & $1.65 \pm 0.91^{\mathrm{acA}}$ & $0.87 \pm 0.48^{\mathrm{bdB}}$ & $1.14 \pm 0.64^{\mathrm{adB}}$ & $<0.0001$ \\
\hline G15 & $3.32 \pm 1.24^{\mathrm{bdA}}$ & $2.16 \pm 0.92^{\mathrm{aB}}$ & $2.21 \pm 1.00^{\mathrm{adB}}$ & $2.17 \pm 1.04^{\mathrm{adB}}$ & $2.10 \pm 0.87^{\mathrm{bB}}$ & $<0.0001$ \\
\hline $\mathrm{P}$ & $<0.0001$ & $<0.0001$ & $<0.0001$ & $<0.0001$ & $<0.0001$ & \\
\hline
\end{tabular}

values are given as means $\pm \mathrm{SD}(\mathrm{n}=6)$

a,b,c,d - in the columns indicate statistical difference between groups

$A, B, C, D$ - in the rows indicate statistical difference between the small intestine parts in each group. Kruskal-Wallis test followed by the Dunn's Multiple Comparison test

Feeding with milk formula (C7) and ghrelin supplementation in a lower dose (G7.5) reduced the mitotic index in all parts of small intestine as compared with sow reared piglets (C7SR), especially in jejunum and ileum. Exogenous ghrelin administration (G15) caused a significant increase of mitotic index $(<0.0001)$ in all parts of small intestine as compared with other groups (C7, C7SR, G7.5).

\section{DISCUSSION}

The previous study has shown that ghrelin exhibits various actions in gastrointestinal tract of both adults and foetal. Moreover, several researches have shown that ghrelin influences cell proliferation in several cell lines. To the best of our knowledge it is the first study showing a direct stimulatory effect of exogenous ghrelin administration on the proliferation activity in the small intestine mucosa in vivo. This finding is crucial because in the early postnatal period crypt cell proliferation is a very dynamic process essential for changes in the crypt-villus axis structure. Moreover, we have shown that the ghrelin effect is dose dependent. The cellular and molecular action of ghrelin in the small intestine mucosa is 
currently unknown. However, the researches on cell lines have shown that ghrelin up regulates cAMP which induces the cell proliferation by the activation of the Extracellular Signal Regulated Kinase 1/2 (ERK) cascade in different cell types (Baldanzi et al., 2002; Stork et al., 2002; Karbonits et al., 2004) including pancreatic $\beta$-cell lines (Granata et al., 2007).

Additionally, our present study has shown that the replacement of sow's milk (C7SR) with milk formula (C7) inhibits the mitotic activity in the small intestine mucosa. This result is consistent with our previous study (Woliński et al., 2003) on the small intestine histometry and enzyme activity and confirms that milk formula inhibits the growth of the small intestine as well as slows up the maturation of the intestinal mucosa. The significant increase in mitotic activity in G15 group as compared to $\mathrm{C} 7$ and C7SR suggests that ghrelin may influence maturation of the gut mucosa and requires further investigation on this subject.

Another objective of the present experiment was to determine the ghrelin effect on the body weight and organ morphometry. Although the exogenous ghrelin treatment has been shown to stimulate body weight gain in weaning pigs (Salfen et al., 2004) in our experiment we have observed an opposite effect. Those differences can be explained in several ways. Firstly, in our experiment piglets were fed via an "artificial sow system" providing equal amounts of milk replacement to all piglets whereas Salfen et al. (2004) experiments provided free access to water and commercial starter feed. Equal feeding procedure in our experiment was a result of a not fully developed centre of appetite and satiety in an early postnatal period. Secondly, we examined the rat origin ghrelin, which was administrated intragastric in the doses of 7.5 and $15 \mathrm{ug} / \mathrm{kg} \mathrm{BW}$, respectively. In Salfen et al. (2004) experiments piglets were infused via jugular catheter with human ghrelin in the dose of $2 \mathrm{ug} / \mathrm{kg}$ BW. Interestingly, we observed an increase in the stomach weight in both groups of ghrelin treated piglets. Stomach is a regarded as a main place of ghrelin production and ghrelin immunoreactive cells (Korbonits et al., 2004). However, in newborn humans and rodents the number of ghrelin cells in the stomach is low after birth until weaning when the ghrelin cell population is greatly expanded (Hayashida et al., 2002; Fak et al., 2007). That may explain decrease in the thickness of the stomach mucosa layer together with increase in muscularis layer observed in the ghrelin group (G15) as compared to control (C7), (Woliński et al., unpublished data). Therefore, increase in the stomach weights in the ghrelin groups (G7.5; G15) in our present experiment maybe rather a trophic effect of peripheral action of the ghrelin administrated to the stomach in this stage of piglet's development.

\section{CONCLUSIONS}

In conclusion, our results show that ghrelin stimulates crypt cell proliferation in the small intestine mucosa. Moreover ghrelin treatment resulted in a slight 
(G7.5) and significant (G15) reduction of body weight as compared with the control groups (C7SR, C7). However, we observed a significant increase in the stomach weight in the piglets treated with both doses of ghrelin. All together suggest ghrelin multiple action in gastrointestinal track of neonatal piglets.

\section{ACKNOWLEDGEMENT}

We thank I. Kato and A. Kuwahara for rat ghrelin (Yanaiara Institute, Japan).

\section{REFERENCES}

Baldanzi G., Filigheddu N., Cutrupi S., Catapano F., Bonissoni S., Fubini A., Malan D., Baj G., Granata R., Broglio F., Papotti M., Surico N., Bussolino F., Isgaard J., Deghenghi R., Sinigaglia F., Prat M., Muccioli G., Ghigo E., Graziani A., 2002. Ghrelin and des-acyl ghrelin inhibit cell death in cardiomyocytes and endothelial cells through ERK1/2 and PI 3-kinase/AKT. J. Cell Biol. 159, 1029-1037

Baudet M.L., Harvey S., 2003. Ghrelin-induced GH secretion in domestic fowl in vivo and in vitro. J. Endocrinol. 179, 97-105

Dembinski A., Warzecha Z., Ceranowicz P., Tomaszewska R., Stachura J., Konturek S.J., Konturek P.C., 2003. Ghrelin attenuates the development of acute pancreatitis in rat. J. Physiol. Pharmacol. 54, 561-573

Fak F., Friis-Hansen L., Westrom B., Wierup N., 2007. Gastric ghrelin cell development is hampered and plasma ghrelin is reduced by delayed weaning in rats. J. Endocrinol. 192, 345-352

Granata R., Settanni F., Biancone L., Trovato L., Nano R., Bertuzzi F., Destefanis S., Annunziata M., Martinetti M., Catapano F., Ghe C., Isgaard J., Papotti M., Ghigo E., Muccioli G., 2007. Acylated and unacylated ghrelin promote proliferation and inhibit apoptosis of pancreatic betacells and human islets: involvement of $3^{6}, 5^{6}$-cyclic adenosine monophosphate/protein kinase A, extracellular signal-regulated kinase 1/2, and phosphatidyl inositol 3-Kinase/Akt signaling. Endocrinology 148, 512-529

Gualillo O., Caminos J., Blanco M., Garcia-Caballero T., Kojima M., Kangawa K., Dieguez C., Casanueva F., 2001. Ghrelin, a novel placental-derived hormone. Endocrinology 142, 788-794

Hayashida T., Nakahara K., Mondal M.S., Date Y., Nakazato M., Kojima M., Kangawa K., Murakami M., 2002. Ghrelin in neonatal rats: distribution in stomach and its possible role. J. Endocrionol. $173,239-245$

Kojima M., Hosoda H., Date Y., Nakazato M., Matsuo H., Kangawa K., 1999. Ghrelin is a growthhormone-releasing acylated peptide from stomach. Nature 402, 656-660

Korbonits M., Goldstone A.P., Gueorguiev M., Grossman A.B., 2004. Ghrelin a hormone with multiple functions. Front. Neuroendocrinol. 25, 27-68

Maccarinelli G., Sibilia V., Torsello A., Raimondo F., Pitto M., Giustina A., Netti C., Cocchi D., 2005. Ghrelin regulates proliferation and differentiation of osteoblastic cells. J. Endocrinol. 184, 249-256

Masuda Y., Tanaka T., Inomata N., Ohnuma N., Tanaka S., Itoh Z., Hosoda H., Kojima M., Kangawa K., 2000. Ghrelin stimulates gastric acid secretion and motility in rats. Biochem. Biophys. Res. Commun. 276, 905-908 
Pettersson I., Muccioli G., Granata R., Deghenghi R., Ghigo E., Ohlsson C., Isgaard J., 2002. Natural (ghrelin) and synthetic (hexarelin) GH secretagogues stimulate H9c2 cardiomyocyte cell proliferation. J. Endocrinol. 175, 201-209

Rindi G., Necchi V., Savio A., Torsello A., Zoli M., Locatelli V., Raimondo F., Cocchi D., Solcia E., 2002. Characterisation of gastric ghrelin cells in man and other mammals: studies in adult and fetal tissues. Histochemistry Cell Biol. 117, 511-519

Salfen B.E., Carroll J.A., Keisler D.H., Strauch T.A., 2004. Effects of exogenous ghrelin on feed intake, weight gain, behavior, and endocrine responses in weanling pigs. J. Anim. Sci. 82, 19571966

Sibilia V., Rindi G., Pagani F., Rapetti D., Locatelli V., Torsello A., Campanini N., Deghenghi R., Netti C., 2003. Ghrelin protects against ethanol-induced gastric ulcers in rats: studies on the mechanisms of action. Endocrinology 144, 353-359

Stork P.J., Schmitt J.M., 2002. Crosstalk between cAMP and MAP kinase signaling in the regulation of cell proliferation. Tr. Cell Biol. 12, 255-266

Woliński J., Biernat M., Guilloteau P., Weström B.R., Zabielski R., 2003. Exogenous leptin controls the development of the small intestine in neonatal piglets. J. Endocrinol. 177, 215-222

Woliński J., Kotunia A., Romanowicz K., Słupecka M., Zabielski R., 2006. Ghrelin is present in swine colostrum, milk and plasma. Regul. Peptides 135, 167 (Abstr.) 